\title{
TITLE:
}

\section{COMPOSITION OF THE FIXED SEA URCHIN COLONY ON HATAKEZIMA ISLAND, 1975}

\section{AUTHOR(S):}

Imafuku, Michio; Tokioka, Takashi

\section{CITATION:}

Imafuku, Michio ... [et al]. COMPOSITION OF THE FIXED SEA URCHIN COLONY ON HATAKEZIMA ISLAND, 1975. PUBLICATIONS OF THE SETO MARINE BIOLOGICAL LABORATORY 1976, 22(6): 403-403

ISSUE DATE:

1976-02-28

URL:

http://hdl.handle.net/2433/175910

RIGHT: 


\section{COMPOSITION OF THE FIXED SEA URCHIN COLONY ON HATAKEZIMA ISLAND, 1975}

The regular observation was made on April 26, 1975, around noon from 11:30 to $12: 30$. It was cloudy and quite calm; the water was lowest, $-8 \mathrm{~cm}$, at $12: 04$. The lower zone of the shore was thickly covered by Hizikia fusiforme Okamura which was just being harvested, but the sea urchin colony examined was completely exposed below the belt of this brown alga. The ratio of the number of Echinostrephus to that of Anthocidaris (E/A) was 1.729. This ratio and actual individual numbers of respective species were nearly the same as in 1974.

\begin{tabular}{l|c|c|c|c|c|c}
\hline \hline \multicolumn{1}{c|}{ April 26, 1975 } & $\begin{array}{c}\text { Section 1 } \\
(\mathrm{SW})\end{array}$ & $\begin{array}{c}\text { Section 2 } \\
(\mathrm{NW})\end{array}$ & $\begin{array}{c}\text { Section 3 } \\
(\mathrm{SE})\end{array}$ & $\begin{array}{c}\text { Section 4 } \\
(\mathrm{NE})\end{array}$ & Total & Percent \\
\hline Anthocidaris crassispina & 49 & 65 & 75 & 59 & 248 & 32.4 \\
\hline Echinostrephus aciculatus & 57 & 186 & 97 & 89 & 429 & 56.1 \\
\hline Echinometra mathaei & 9 & 26 & 25 & 28 & 88 & 11.5 \\
\hline
\end{tabular}

The complete absence of Mespilia in April was noted with a fear for possible water-pollution in the area. Thus, further observation was made around noon on June 11 to see if there occurred some Mespilia in this advanced season with higher water temperature and to confirm the stability of the population composition. It was fine and a breeze came from the west. The water was lowest, $0 \mathrm{~cm}$, at 12:53. As the colony was not exposed, it was rather difficult to carry out the observation exactly. The boundaries of the colony were somewhat obscure and some smaller specimens might be overlooked. Nevertheless, it was found that the composition was maintained very similarly and Mespilia was wholly absent. The ratio E/A was 1.718 .

\begin{tabular}{c|c|c|c|c|c|c}
\hline \hline June 11, 1975 & $\begin{array}{c}\text { Section 1 } \\
(\mathrm{SW})\end{array}$ & $\begin{array}{c}\text { Section 2 } \\
(\mathrm{NW})\end{array}$ & $\begin{array}{c}\text { Section 3 } \\
(\mathrm{SE})\end{array}$ & $\begin{array}{c}\text { Section 4 } \\
(\mathrm{NE})\end{array}$ & Total & Percent \\
\hline Anthocidaris crassispina & 36 & 59 & 65 & 67 & 227 & 33.0 \\
\hline Echinostrephus aciculatus & 55 & 138 & 89 & 108 & 390 & 56.7 \\
\hline Echinometra mathaei & 8 & 10 & 19 & 34 & 71 & 10.3 \\
\hline
\end{tabular}

Michio IMAFUKU and TAKASI TOKIOKA

Publ. Seto Mar. Biol. Lab., XXII, 403, 1976.

(Biological data 1) 